\title{
Integrating Sustainable Water Resource Management and Land Use Decision-Making
}

\author{
Heidi L. N. Moltz *, Carlington W. Wallace ${ }^{\circledR}$, Erfaneh Sharifi and Karin Bencala \\ Interstate Commission on the Potomac River Basin, Rockville, MD 20850, USA; cwallace@icprb.org (C.W.W.); \\ esharifi@icprb.org (E.S.); bencalak@gmail.com (K.B.) \\ * Correspondence: hmoltz@icprb.org
}

Received: 29 July 2020; Accepted: 10 August 2020; Published: 13 August 2020

\begin{abstract}
Human uses of land and water are directly linked and must, therefore, be managed with each other in mind. This paper puts forward an approach for integrating sustainable water resource management into local land use decision-making in the Potomac basin. The approach includes developing a clear understanding of the current regulatory, programmatic, and financial approaches to land use management; identifying opportunities from innovation; and developing a flexible, stakeholder-based framework for moving forward. Four opportunities for innovation were identified in the Potomac basin utilizing this approach, including enhancing coordination and access to information, promoting incentives to achieve desired outcomes, encouraging and promoting innovation, and integrating programs to achieve multiple objectives. The successful integration of land and water decision-making requires a sustained, long-term commitment to improvement rather than a one-time fix mentality. Initial steps for implementation include identifying and engaging diverse partners, as well as establishing channels for information dissemination. The lessons learned from this work may prove valuable to decision-makers in other regions to holistically manage diverse land and water resources.
\end{abstract}

Keywords: watershed management; planning; land use/land cover change; Potomac River

\section{Introduction}

Land and water issues are inextricably linked. Each component of the water cycle, from evaporation to precipitation, surface runoff, infiltration, and groundwater flow, affects or is affected by anthropogenic factors [1]. The impacts of land management on the quality and quantity of sustainable water resources are well documented in the literature [2-5]. Each land use type (e.g., urban, agriculture, and forest) has specific, scale-dependent effects [6,7] on surface- and ground-water ecology, availability, demands, and quality [8-13]. The successful management of one (land or water resources) should by default involve the consideration of the other [14]; however, this is rarely the case. The importance of shifting paradigms around the world to integrate land and water management has been documented by the United Nations [15]. Studies from the United States, China, and Thailand among others have demonstrated the need and importance of integration [11-13].

This paper describes (1) strategies for implementing land-based practices and integrating land and water management objectives, (2) challenges to implementing those strategies, and (3) opportunities for innovation that would assist in addressing identified challenges - with the ultimate goal of defining a strategy for sustainable land-water management. As described in more detail in subsequent sections, this work was conducted by analyzing planning documents at various spatial scales (regional, county, and local) and conducting an extensive literature review of case studies from around the world.

The Interstate Commission on the Potomac River Basin (ICPRB) is a non-regulatory organization with a mission to preserve and protect the basin's resources endeavors to understand current land 
management approaches in the basin, identify opportunities for innovation, and articulate steps for strengthening the land-water management nexus in the Potomac basin using an adaptable approach that is flexible to shifting stakeholder and basin needs. Current approaches for the implementation of land management activities are reviewed under three categories: regulatory, programmatic, and financial. Innovative approaches that might be adopted in the Potomac basin to improve the quality and quantity of both land and water resources are also examined. As the implementation of novel approaches requires collaboration, a partner identification and development component are discussed, as it will be essential to the stakeholder-driven implementation process. The paper also proposes an approach for disseminating timely information to stakeholders to inform sound decision-making.

The ideas contained in this manuscript are built on an Integrated Water Resources Management (IWRM) framework. IWRM, according to the Global Water Partnership, is defined as "a process which promotes the coordinated development and management of water, land and related resources in order to maximize economic and social welfare in an equitable manner without compromising the sustainability of vital ecosystems and the environment". By definition, this approach calls for the joint consideration of land and water management, built on the foundation of a cross-disciplinary commitment for engagement. For years, water resources professionals have communicated a call to action for IWRM that, among other integrations, brings together land and water resources management into a common discussion of sustainable resource management [16].

Identifying a conceptual approach for sharing timely water resources information to land use decision-makers is a valuable tool that may be adopted for other river basins around the globe $[5,15]$. Incorporating flexibility, innovation, and collaboration into land and water management frameworks is essential, particularly given the uncertainties faced by managers and decision-makers (i.e., climate change) $[17,18]$. In fact, climate change and land use have been considered the primary drivers of uncertainty for water resource planning [19]. As such, the lessons learned from this work may prove valuable to decision-makers in other regions to holistically manage land and water resources. This approach may be especially valuable in diverse basins that span jurisdictional boundaries.

\subsection{Study Area}

The Potomac basin spans approximately 14,670 square miles in the Mid-Atlantic region of the United States. The basin includes portions of Virginia, Maryland, West Virginia, and Pennsylvania, as well as the entire District of Columbia (Figure 1). The Potomac River is a tributary of the Chesapeake Bay and is the second largest contributor of fresh water to the bay. The river itself is a dividing line between basin jurisdictions.

The Potomac basin is highly varied, including relatively steep-sloped forested headwaters, rolling agricultural lands, heavily urbanized metropolitan areas, and low-lying coastal plains. Land use in the basin is comprised of 53 percent forest, 26 percent agriculture, 14 percent developed, and 7 percent other [20]. Urbanization has been deemed the leading driver of water and habitat degradation in the Potomac basin and the larger Chesapeake Bay drainage area [21].

Due to its diverse physical and anthropogenic characteristics, each region in the basin faces land management challenges, ranging from acid mine drainage to agricultural runoff and impervious cover to name a few. A holistic, basin-wide approach to sustainable land management is complicated by the different regulations, programs, and financial considerations of each jurisdiction. Each state in the basin has a unique legislative framework for carrying out land and water resource management. A selection of statutes from across the basin include Maryland House Bill 1141 of 2006, West Virginia Senate Bill No. 641 of 2008, Pennsylvania Act 220 of 2002, and Virginia's Title 9 Local and Regional Water Supply Planning Regulation. The nature of the individual statutes guide implementation. In Maryland, for example, water resource planning under the state law is conducted by the entity (county or municipality) that has planning and zoning authority. In West Virginia, the state environmental agency developed a plan and mapping tool to comprehensively evaluate water resources [22]. Decision-making for specific 
land-based activities is primarily carried out at the local level in the Potomac basin. Discussions to improve integrated land-water management must, therefore, include local decision-makers.

A stakeholder-driven comprehensive water resource planning process in the Potomac basin resulted in a renewed desire to promote integrated land and water decision-making [23]. The comprehensive plan was completed in 2018 and included participation from a range of geographically and substantively diverse organizations. The five major topic areas of the plan are ensuring sustainable water use and supplies, protecting and improving water quality, managing human land use for sustainability, protecting ecological health, and addressing challenges that cut across these topic areas (e.g., source water protection, climate change, and floods and droughts). The implementation of the land use component of the plan focuses on enhanced information sharing among land and water managers and stakeholders. The goal is to inform sound land use decision-making that supports sustainable water resource management [23].

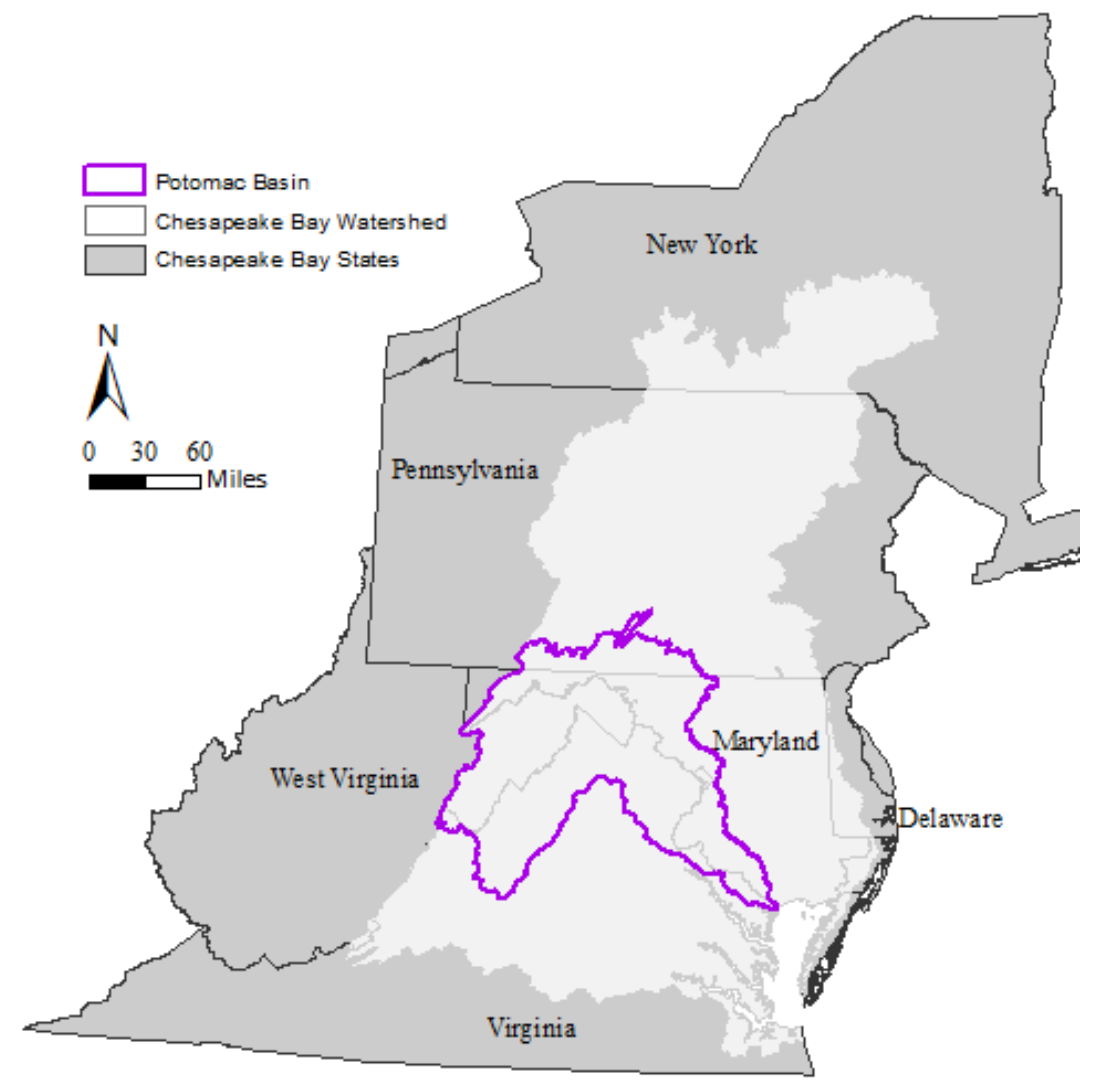

Figure 1. Location of the Potomac basin in the Chesapeake Bay watershed, Chesapeake Bay states, and the District of Columbia.

\subsection{Methods}

The process described in this paper to integrate sound water resources management into land use decision-making in the Potomac basin is shown in (Figure 2). The approach is designed to be adaptive and flexible to shifting stakeholder needs. In addition, it brings together lessons learned from other regions, a deep understanding of the basin in consideration, and a thoughtful stakeholder engagement strategy to disseminate needed information at the right time to the right people. Section 2 of this paper describes the evaluation of the regulations, programs, and financial components of programs implemented in the basin. Section 3 identifies opportunities for innovation in the basin. Section 4 describes how the challenges will be met by engaging stakeholders and implementing a strategy for information dissemination. This approach is widely applicable for multi-jurisdictional basins around the globe. 

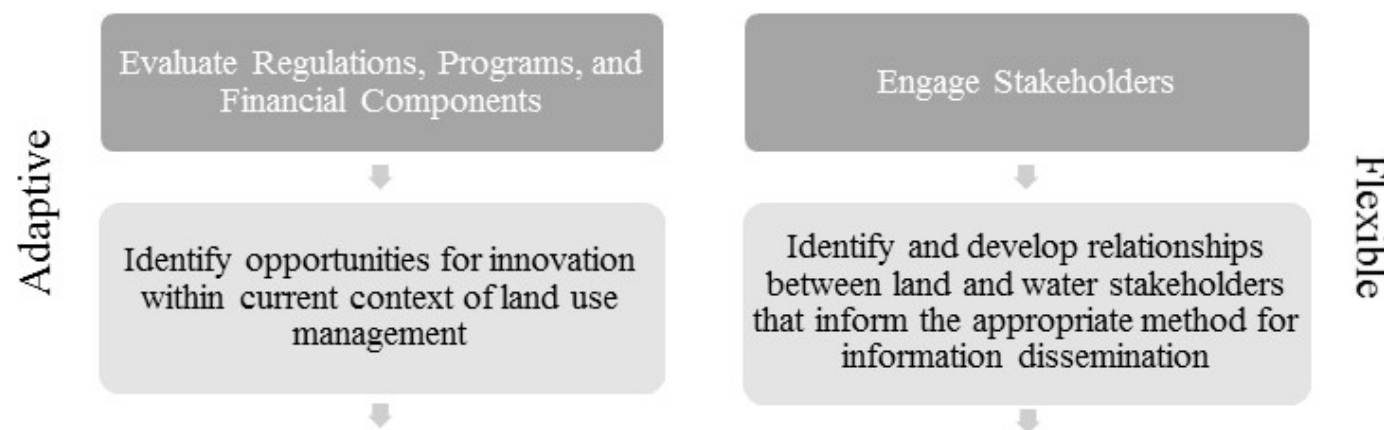

Timely information to key land use decision-makers to promote sound water resources management

Figure 2. Method for integrating sound water resource management activities into land use decision-making in the Potomac basin.

\section{Current Themes for Land Use Management, Potomac Basin}

To understand the priorities and practices of those local authorities, 49 local planning documents from across the Potomac basin were selected and reviewed based on geographic coverage as part of the development of the Potomac Basin Comprehensive Water Resources Plan [23]. The planning documents mainly consist of comprehensive plans, natural resource management plans, and water supply plans. The objective of reviewing the documents was to understand land use planning and management for integration with water management efforts.

Specifically, the plans were reviewed using readily available online materials from 17 counties in Virginia, 9 in Maryland, 5 in West Virginia, 3 in Pennsylvania, and from 15 municipalities across the basin to represent broad geographic diversity across all basin states (Figure 1). The review resulted in an understanding of practices (i.e., specific Best Management Practices, BMPs) promoted through land use planning across the basin that may promote sustainable water resource management [24]. The promoted practices address a range of land uses, including agriculture, forests, residential, commercial and industrial, rural, and shoreline areas.

The regulatory, programmatic, and financial approaches to the implementation of the 49 plans' elements were evaluated based on the recommendation of the Potomac Basin Comprehensive Water Resources Plan advisory committee. The committee was comprised of nearly two dozen professionals from across the basin.

Practitioners in the basin use diverse tactics to implement regulatory, programmatic, and financial approaches, all of which can be highly effective (Table 1) [25,26]. These strategies make a difference in taking any given practice from theory to reality. The application of each approach in the basin is discussed in Sections 2.1-2.3. 
Table 1. Strategies for implementing the regulatory, programmatic, and financial approaches.

\begin{tabular}{|c|c|c|}
\hline Approaches & Strategies for Implementation & Citations \\
\hline \multirow{8}{*}{ Regulatory } & Enforcement & {$[27,28]$} \\
\hline & Monitoring & [28] \\
\hline & Inspection and maintenance & [28] \\
\hline & Permitting & {$[29,30]$} \\
\hline & Tracking and reporting & [31] \\
\hline & Reporting and data management & [32] \\
\hline & Stakeholder involvement & [33] \\
\hline & Lobbying & [34-36] \\
\hline \multirow{10}{*}{ Programmatic } & $\begin{array}{l}\text { Building the land conservation } \\
\text { community }\end{array}$ & [37] \\
\hline & Monitoring cooperatives & [38] \\
\hline & Education and outreach & [37] \\
\hline & Cross-outcome collaboration & [38] \\
\hline & Citizen stewardship & [37] \\
\hline & Roundtables and training & [38] \\
\hline & Networking & [38] \\
\hline & Grass-roots education & [39] \\
\hline & Activism & [39] \\
\hline & Certification & {$[39,40]$} \\
\hline \multirow{10}{*}{ Financial } & Grants & {$[31,41]$} \\
\hline & Financing & {$[41]$} \\
\hline & Tax incentives & [42] \\
\hline & Cost-share & {$[31,43,44]$} \\
\hline & In-kind and supplies & [43] \\
\hline & Rebates & [44] \\
\hline & Utility fee discounts & [44] \\
\hline & Technical assistance & [44] \\
\hline & Credits & [44-47] \\
\hline & Trading & [48] \\
\hline
\end{tabular}

\subsection{Regulatory}

Regulations are an essential component of land and water management in the Potomac basin and across the United States. They establish compliance criteria against which the permitted and regulated entities are evaluated. Not unique to the Potomac basin, regulations are quite effective at managing entities that have point source discharges (e.g., industrial outfalls, nutrient management for Confined Animal Feeding Operations, and Combined Sewer Overflows). Regulations also have limitations. They often lack popular appeal, making them difficult for politicians to implement, and follow-up monitoring and enforcement can be weak or non-existent. While regulations are readily available for agencies to implement for existing permitted or regulated entities, the ability of regulations to address broad, diffused landscape-scale problems is limited (e.g., non-point source water pollution) [49].

There is no single agency with regulatory authority for land use management across the Potomac basin. Due to this, the regulations differ in each of the basin's jurisdictions. There are specific conditions that trigger regulatory mechanisms, including federal, state, and local laws. The applicable federal laws include the Clean Water Act [27], the Endangered Species Act [50], the National Historic Preservation Act of 1966, the Mining Control and Reclamation Act of 1377, and the National Environmental Policy Act of 1969, to name a few. For example, based on section 303(d) of the Clean Water Act, states are required to identify impaired waters (waters not meeting established water quality standards) and allocate the pollutant reductions needed to attain the water quality standards. In the Potomac states and the larger Chesapeake Bay watershed, this legislation is driving local and bay-wide restoration efforts. States also have regulations. As one example, the Maryland Erosion Control Law was established to protect land and water resources from sediment pollution and increased runoff due to active development 
and redevelopment [30]. Zoning ordinances define and implement land use standards at the local level. Loudoun County, Virginia's zoning ordinance, is one example of many; it provides guidelines for subdivisions, permitted and special exception uses, and additional development requirements [29].

While adopting regulations can be a key step in natural resource management, the regulations do not exist in a vacuum. Regulatory implementation requires a web of supportive activities including, but not limited to, monitoring [28], inspection and maintenance [28], enforcement [27,28], permitting [29,30], reporting and data management [32], tracking and reporting [31], lobbying [34-36], and stakeholder involvement [33] (Table 1). For example, monitoring, inspection and maintenance, and enforcement strategies are used to establish requirements and procedures for controlling adverse impacts and to bring violating entities into compliance [28]. Permits, such as zoning permits [50] or construction permits [29], are effective tools to implement regulations, as they include a review process and, often, inspections. Tracking, reporting, and data management tools [31,32] provide key information to relevant parties and enhance the conscious decision-making process. Lobbying is another tool to implement and influence regulations [34,35]. While local and state governments have a clearly defined regulatory role to play, citizens also are an integral part of sustainable regulatory solutions. Stakeholder involvement facilitates a coordinated regulatory effort and can include regional public meetings, public hearings, and media publications, to name a few [33]. The strategies have been discussed here using descriptive examples from the Potomac basin; however, the strategies are broadly applicable to other regions as well.

\subsection{Programmatic}

Programmatic practices support broader goals and complement regulatory authorities. State and local government agencies, local nonprofit organizations, and community groups develop programs to preserve the environment, agriculture, neighborhood characteristics, thriving downtowns, and sustainable working landscapes. For many of these programs to achieve their strategic objectives, the various groups need to coordinate on a tactical level that focuses on the coordinated management of related projects. The Chesapeake Bay Program, for example, is a multi-agency program that brings together diverse stakeholders to restore the Chesapeake Bay, with a goal of ultimately achieving the goals set forth in the Chesapeake Bay Watershed Agreement of 2014. Partners involved in the Bay Program's efforts include federal, state, and local government agencies; academic institutions; nonprofit entities; businesses; and advocacy groups. Another programmatic example from the Potomac basin is Wetlands Watch, a 501(c)(3) nonprofit organization dedicated to protecting wetlands. Since its inception in 1409, the group has tackled issues ranging from adapting to sea level rise to managing floodplains and creating conservation landscapes. Their activities include developing practical guides to inform and activate citizens, promoting and coordinating the Chesapeake Bay Landscape Professional Certification Program, and encouraging open space designations through the National Flood Insurance Program's Community Rating System [39]. Programmatic tools can also assist in achieving programmatic goals. As examples, Wetlands Watch is tackling sea level rise through the development of a crowdsourced flood data phone application [39], and the Stormwater Management and Restoration Tracker program helps control pollution in the Chesapeake Bay by enabling users to commit to adopting practices with nutrient and sediment reductions [40].

Strategies for program implementation in the Potomac basin focus on building relationships, knowledge, awareness, and action. Specific strategies are building the land conservation community [37], monitoring cooperatives [38], education and outreach [37], cross-outcome collaboration [38], citizen stewardship [37], roundtables and training [38], networking [38], grass-roots education [39], activism [39], and certification [39,40] (Table 1). Building the land conservation community as a platform for partners to establish relationships for better communication is one type of effort to convene and act on land and water resources conservation priorities [37]. Consistent education and outreach to officials and communities about the benefits of land use and water resource conservation programs is also necessary for increasing public support [37]. Cross-outcome collaboration and monitoring 
cooperative strategies increase partner capacity to communicate outcomes and engage local officials for implementing programs [38]. Advancing youth engagement and citizen stewardship efforts offer opportunities for residents to reflect on their connection to the environment [37]. Roundtables and training via municipal organizations and state associations are another tool to implement strategies [38]. Networking can enhance conservation efforts [38]. As an example, for education and activism, Wetlands Watch uses grass-roots education and activism strategies to influence local government to develop land use programs and regulatory decisions [40]. Another effective tool to implement programmatic approaches is certification. Certification programs exist in various professional sectors with typical objectives of education, reporting, and ultimately environmental enhancements [39,40].

\subsection{Financial}

Proactive land management requires money. As such, financial mechanisms are an important part of the discussion. Financial assistance and incentive programs can motivate decisions in line with sustainable land use and water resource management principles. Three of many financial approaches in the Potomac basin include tax incentives, cost share, and grants. Discussions on each are provided below. In addition, compilations of specific examples are available through the Environmental Protection Agency (EPA), Chesapeake Bay Trust, Alliance for the Bay, and other funding organizations.

Tax incentives reduce the amount of taxes owed to support the voluntary installation of on-the-ground practices. States and localities throughout the basin have adopted various tax incentives to encourage the adoption of practices for various sectors, including, but not limited to, homeowners, agricultural producers, and developers. For example, in Virginia, agricultural producers may benefit from a BMP tax credit program approved by their Soil and Water Conservation District as part of Virginia's nonpoint source pollution water quality program [42]. In addition, both federal and state governments in the Potomac basin offer tax benefits for restrictions placed on land that help preserve water quality, provided the transaction meets the tests set out in section 170 of the Internal Revenue Code. The exact amount of available tax incentives varies and are subject to several important qualifications. In general, however, the gift of an easement is a charitable donation that may be deducted from federal income taxes. The value of the donation is determined by an appraisal. If this value is $50 \%$ or less of the landowner's adjusted gross income, it may be entirely deducted in one year. If the value is greater, it may be spread over as many as 15 years. Virginia law provides a more generous benefit by allowing a Virginia income tax credit for 42 percent of the value of donated land or conservation easements. Taxpayers may use up to $\$ 20,000$ per year through 2020 and $\$ 50,000$ per year in subsequent tax years. Tax credits may be carried forward for up to 13 years. Unused credits may be sold, allowing individuals with little or no Virginia income tax burden to take advantage of this benefit.

Qualified landowners can install conservation practices through cost share programs funded by federal, state, and/or agency resources. These programs pay for a percentage of the conservation practices established and maintained by the landowner. The United States Department of Agriculture (USDA) Natural Resources Conservation Service (NRCS) offers considerable cost share opportunities with federal dollars for agricultural producers in the basin and around the country [51]. An example of local cost share funding is the Fairfax County, Virginia, Conservation Assistance Program for Civic/Homeowners Associations and Places of Worship [52], which matches funds for watershed conservation projects.

Grant programs provide technical and financial assistance for eligible landowners to apply conservation practices and are often initiated through universities, governmental organizations, and nonprofits, among others. Grant programs provide funding (often competitively) for selected projects that do not need to be repaid. Grants for implementation activities in the Potomac basin and the larger Chesapeake Bay watershed are available from many sources (e.g., [53-55]). For example, the Chesapeake Bay Grant Implementation program uses federal funds and a non-federal match to fund the implementation of natural filters [31]. The Chesapeake Bay Green Streets, Green Jobs, Green Towns (G3) Grant Program supports the design, financing, and/or implementation of green street projects [41]. 
EPA financial assistance through the Clean Water Act [43] and the Chesapeake Bay Program is another source of funding in the Potomac basin to support the conservation and land use practices affecting water resources.

In addition to the tax incentives, cost share programs, and grant programs, other strategies for the implementation of financial approaches in the Potomac basin include financing [41], in-kind and supplies [43], rebates [44], utility fee discounts [44], technical assistance [44], credits [44-47], and trading [48]. An example for the in-kind and supply strategy is EPA in-kind, which is the dollar value associated with providing space and supplies for grantees located on-site at EPA [43]. Other tools to implement financial approaches include rebates, utility fee discounts, technical assistance, and direct cost-share [44]. These tools support residential owners to install stewardship practices to help reduce runoff and pollutants from their property [44]. Landowners can create credits by implementing conservation practices and sell credits to organizations or entities such as wastewater treatment plants and construction and development firms [46]. Nutrient trading is another financial tool for pollution reduction $[45,48]$.

\subsection{Existing Challenges}

The previous sections outline current regulatory, programmatic, and financial themes for land use management. A multitude of activities are underway in each of these areas and great progress has been made; however, implementation challenges exist. Specifically, three major challenges were identified: communication/education, the availability of information, and funding. Each of these is discussed below.

Effective education and communication are vital to encouraging stakeholders to act, increasing the knowledge of local officials to help them manage natural resources more effectively, raising the next generation as stewards of the environment, and enhancing the awareness of potential funding sources [38].

Identifying funding sources for related initiatives in response to a changing political climate and uncertain budgets is challenging [37]. Funding is not always secure for land conservation and other related land and water resource management activities. It requires an ongoing effort to sustain dedicated funding streams [37].

Ensuring sound, fact-based information is in the right hands at the right time for sustainable resources management is also a challenge. This may include the development of streamlined conservation practices reporting processes [44], developing tools at the appropriate spatial scale for decision-makers [42], and developing readily available baseline and other needed data sets [56]. This promotes a coordinated, informed approach to achieving common goals.

Potomac basin efforts have been quite successful, achieving advances towards improving the quality, quantity, and health of the river; however, there is much more work remaining to ensure sustainable supplies for human and ecosystem needs [23]. The next section of this paper identifies opportunities for innovation in the Potomac basin to overcome the existing challenges.

\section{Opportunities for Innovation in the Potomac}

Numerous studies investigate how to promote implementation of desired boots-on-the-ground practices for objectives, including adapting to climate change, preventing the spread of invasive species, and promoting sustainable food systems, to name a few [57-64].

Based on an extensive literature review, this paper identifies four opportunities for innovation in the Potomac that enhance the current regulatory, programmatic, and financial approaches for integrating land and water management and address the existing challenges identified in this study. The four opportunities discussed here are (1) improving access to information, (2) promoting incentives to achieve desired outcomes, (3) developing a framework that encourages innovation, and (4) integrating programs to achieve multiple objectives. These four opportunities build on one another and are, at the same time, infused in one another (Figure 3). No single innovative approach is adequate under all 
circumstances, requiring the locale-specific adoption of appropriate strategies and inherent flexibility to adapt over time [25,65]. A rationale for incorporating each of these in the Potomac strategy is discussed in turn below. The discussions include land use planning case studies related to farmers markets, housing, green infrastructure, and placemaking.

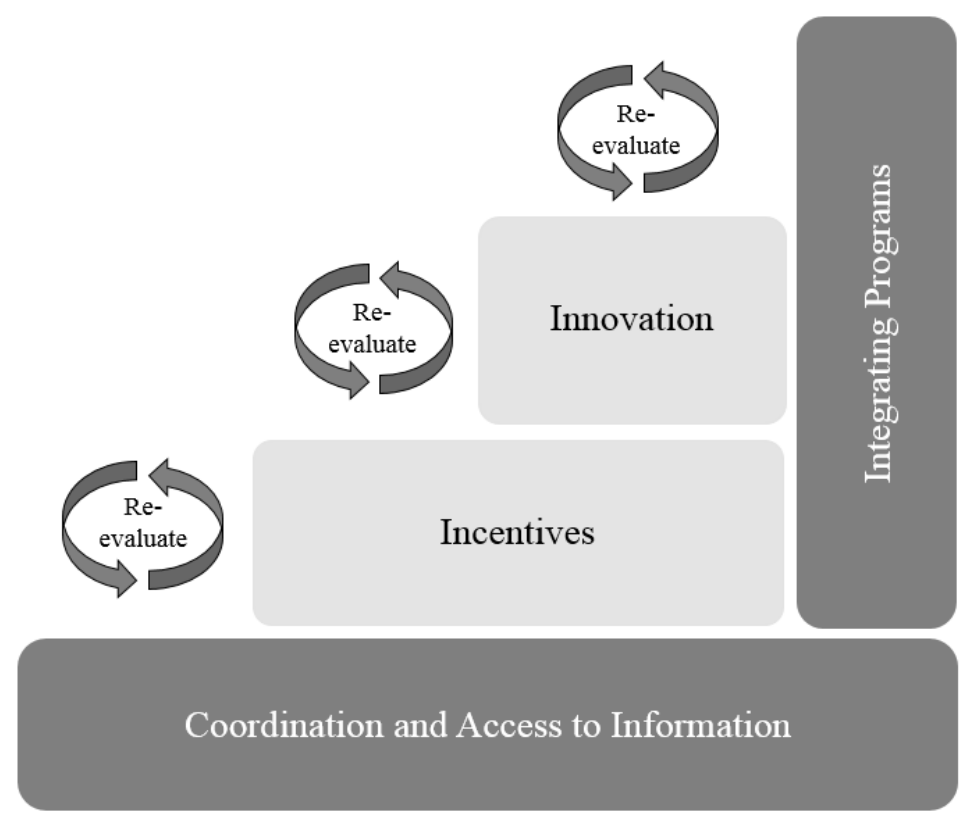

Figure 3. Related nature of the opportunities for innovation and the built-in process for flexibility and adaptability over time.

\subsection{Enhancing Coordination and Access to Information}

While a great deal of water resource information is available online, land use decision-makers often have limited time to research current and reliable water resource information to inform their actions. Therefore, more emphasis should be placed on enhancing deliberately planned coordination [56], access to information [23,57], and creating opportunities for water professionals to engage with land use decision-makers [27]. By coordinating in focused, meaningful ways, decision-makers will have more of the needed water resources context to promote incentives, encourage innovation, and integrate programs.

With advancement in technology, the acquisition, management, and use of data have improved significantly with time and have made it easier for agencies to coordinate and disseminate information to support decision making in a timely manner. For example, the ESRI ArcGIS Online platform that was introduced in 2001 [66] now uses cloud-based technology that allow users to access their work at any time, from anywhere, and to share interactive maps with millions of people at the same time [67].

The case study presented below is another example of how enhanced coordination between decision makers and stakeholders leads to a more environmentally friendly and sustainable approach to farmers markets, especially in terms of water resource management.

\section{Case Study: Support Existing and Create New Farmers Markets}

Farmers markets are becoming increasingly popular as consumers desire more locally grown, organic produce. The focuses of farmers market customers are quality food and farming practices [66]. A recent study by [68] found that farmers that sell their produce in the farmers markets are more likely to adopt environmentally sound farming practices consistent with organic standards. Such practices include on-site composting, integrated pest management, rainwater harvesting, and nutrient management [68]. Further, the products sold at farmers markets travel significantly less 
distance from the source [69]. By bringing together key stakeholders and taking advantage of land use opportunities, barriers can be removed to bringing farmers markets to new areas.

As one example, the city of Fresno, California, amended their zoning regulations to define farmers markets as a permitted use. This provision allows farmers markets to be established and maintained in approved zones without requiring a permit, finding, variance, or other land use approval. Farmers markets may also be located on park land if they are not significantly interfering with the public use and enjoyment of other areas of the park. As a result, markets have sprouted up on the grounds of public facilities, local schools, and other creative locations [70]. The farmers markets support farmers in making a living off sustainably grown food while providing increased access to fresh produce, especially for low-income communities by requiring the acceptance of food assistance.

Adopting and optimizing this type of land use framework necessarily includes coordination between multiple stakeholder groups, including land use decision-makers, farmers, and community members, reaping benefits for the community as well as the land and water resources [71-73].

In the Potomac basin, farmers markets offer an exciting opportunity to maximize the use of public spaces that are currently underutilized. In metropolitan areas, where confined parks and impervious surfaces such as parking lots generate excessive runoff during storm events, the farmers markets would encourage rainwater harvesting and the sustainable use of these public spaces, especially when agricultural lands are being converted to residential and commercial uses.

\subsection{Promoting Incentives to Achieve Desired Outcomes}

Financial incentives are becoming increasingly popular to encourage the implementation of land use management strategies either with or without complementary regulation [74]. The adoption of more incentive programs has been called for in the broader Chesapeake Bay watershed [75-77]. Limited federal financial incentives require states and local agencies to find innovative financial solutions to achieve goals. Local incentive programs are well documented and commonly include fee discounts, development incentives, grants, rebates and installation financing, and awards and recognition programs, among others [78,79]. A national compilation of rainwater and water conservation incentives is available through HarvestH20 and includes numerous examples from many of these categories [80]. Effective communication and outreach about existing or new incentive programs will be essential for a program's success [81].

An example of incentives to promote both land and water resource benefits relates to affordable housing. Incentives for affordable housing projects are popular within the Potomac basin, particularly in Maryland; however, they are very competitive and highly regulated. The case study presented below highlights a city in New Hampshire that has found an innovative solution to incentivize developers that implement land use management strategies when constructing residential units.

\section{Case Study: Inclusionary Housing Ordinance}

Conventional housing development has contributed to urban sprawl and challenges our ability to minimize negative water quantity (e.g., stormwater) and water quality (e.g., erosion and sedimentation) impacts [82]. While affordable housing projects do not solve the environmental problems associated with urban sprawl directly, they go a long way in bridging the gap between housing availability and proximity to jobs, reducing the rate at which rural lands are converted to suburban housing developments.

The City of Exeter, New Hampshire, incorporated an inclusionary housing ordinance into the zoning provisions for "elderly congregate health care facilities and open space development," which grants a 15 percent density bonus in exchange for 20 percent of the total number of proposed units provided as "affordable." This inclusionary housing ordinance was implemented in the Watson Road mixed income subdivision, which has 86 single family homes, 20 of which are two-bedroom condominiums priced at $\$ 180,000$ and up. Another eight units are priced starting at $\$ 300,000$. The remaining homes begin at $\$ 400,000$. Income limits have been set for prospective buyers. While 
the affordable units were priced about $\$ 60,000$ below their market value, the combined benefits of the density bonus and higher cost unit revenues will offset the price reduction.

Working together to find innovative ways to incentivize sustainable land and water management while also promoting other community objectives such as affordable housing is a win-win. By engaging with land use decision-makers, community members, and professionals, novel opportunities for incentive-based programs (such as the density bonus program) can be identified in the Potomac as well.

\subsection{Developing a Framework that Encourages Innovation}

Innovation is key in this era of increasing water resource uncertainty $[83,84]$. Constructing a flexible regulatory, programmatic, and financial framework that encourages adapting and innovating is essential. The literature delivers mechanisms for creating incentives for innovation [85-87] and is ripe with case studies of successful innovation related to both land $[88,89]$ and water resources $[90,91]$. Conservation easements, the application of solar energy technology, and affordable financing for clean energy are just few of the successful innovations for land management. Examples of successful innovation in water resources include the reclamation and reuse of waste water project in the Greater Chicago area, the building of a "Green City by a Blue Lake" in Cleveland Ohio, and the creation of a tech hub for advanced water solutions in the Twin City region of Minnesota [91].

The Potomac basin itself is home to some nationally recognized innovations, such as DC Water's Blue Plains Advanced Treatment Plant's electric generation capability [92]; however, innovation is not a "once and done" idea. It is a mindset, an ongoing evolution of strategy and practice. The key components of successful innovation, as discussed by [88], include having the capacity to identify and evaluate opportunities and threats, proactively address areas of uncertainty, create the needed organizational capacity to do something new, and overcome barriers to success. A focused effort on creating and encouraging a space for innovation is paramount for sustainable land and water management in the basin. The case study presented below highlights an innovative program that currently exists in Montgomery County, Maryland, in the Potomac basin.

\section{Case Study: Green Infrastructure to Control Combined Sewer Overflows}

A portion of the District of Columbia's sewer system is made of combined sewers. Combined sewers carry sewage during dry weather and both sewage and rainfall runoff during wet weather. During storms, the combined system can become overwhelmed with the combined volume of sewage and rainfall runoff, releasing the untreated mixture into surface waters. These releases are termed Combined Sewer Overflows. The District of Columbia is implementing a green infrastructure program as one piece of the puzzle to control Combined Sewer Overflows [93]. Green infrastructure controls stormwater through natural measures such as trees and plants that can remove pollutants (thereby contributing to the achievement of Chesapeake Bay restoration goals), reduce temperature, and slow down stormwater flows that contribute to localized flooding and erosion. The benefits of green infrastructure reach far beyond stormwater control. Additional benefits include providing wildlife habitat, improving public health, enhancing urban aesthetics, and increasing property values, to name a few. To successfully implement this program, the regulatory, programmatic, and financial frameworks had to exist and/or adapt to accommodate these new ideas.

\subsection{Integrating Programs to Achieve Multiple Objectives}

Leveraging resources to achieve common goals makes sense, but it can be difficult to make this dream a reality, given traditional silos in many aspects of government and community. Water issues and their policy-based controls impact human land uses in very real ways, and vice versa. These issues include, but are not limited to, outdated policies and procedures [94], inadequate/degraded infrastructure, excessive water withdrawals, degrading water quality from point and non-point sources, the alteration of flood plain and wildlife habitat from development activities, and the alteration of 
overland and subsurface flow routing [95]. Managing water resources and land use planning in an integrated way can save time, money, and conflict over time [96].

There are local, regional, and national calls to integrate the planning and management of water and land resources $[57,76,97]$. Most water resource and land use planning-integration approaches found in the literature focus on new developments $[96,98]$ rather than repurposing existing developments to enhance sustainability. The case study below provides an example of how policy makers, private and public institutions, and community members can work together to improve placemaking through integrated planning and management strategies that achieve multiple objectives.

\section{Case Study: Placemaking}

The city of Minneapolis, Minnesota, is utilizing a "creative placemaking" policy to bring together city stakeholders to use arts and cultural strategies to implement community-led land use development. Two recent projects, Juxtaposition Arts (started in 2004) and Made Here (started in 2013), helped to shape the physical and social character of the city. They engage artists and residents to change vacant spaces into community spaces and highlight the unique characteristics of the city. Juxtaposition Arts has converted five vacant spaces into social-enterprise studios that provide training and employment opportunities to youths in visual arts and other related fields and produce design products and services for sale to local and national customers. The Made Here initiative filled underused storefronts and commercial spaces with art by local artists and transformed Hennepin Avenue in Minneapolis into a walkable urban art gallery. According to Minneapolis Center for Community Progress, opportunities for creative placemaking include developing partnerships between businesses, local organizations and individuals; expanding planning and economic development strategies to incorporate placemakers and community-based organizations; identifying vacant structures for repurposing; and helping creative organizations navigate zoning and permitting process. Placemaking identifies community challenges, such as barriers to quick permitting requests and vacancy patterns in an inclusive manner; engages diverse stakeholders, such as traditional and neighborhood-based organizations; and gathers ideas to decide on creative placemaking actions.

This innovation in placemaking provides opportunities to integrate programs to achieve multiple objectives, as these activities may be based on a variety of community objectives, such as sustainable water resource management, climate change resilience, livable urban areas, smart growth, and many more.

There are many potential water resources benefits of placemaking. An effort to renovate or repurpose abandoned lots and buildings, as this case study illustrates, can minimize the need for new construction that often encroaches on agricultural and forested lands, disrupting surface and subsurface flow routing processes [99-101]. The result is a reduced negative impact on water and environmental resources from human activities. The impacts of urbanization on stream water quantity and quality has been well documented in the literature [4,9,102-104].

\section{Meeting the Challenges}

Jointly managing land and water resources for the benefit of both is no small task and requires interdisciplinary thought and diverse stakeholder involvement. The Potomac Basin Comprehensive Water Resources Plan [23], as well as [105], urge decision-makers in the basin to make this a reality. This paper describes the approaches currently employed in the basin (regulatory, programmatic, and financial), opportunities for innovation in the basin, and the initial steps needed for successful implementation. With this approach in hand, the next steps can be taken towards making the plan's land use vision a reality.

The call for this type of approach is clear in the literature $[5,15]$ and in the creation of scenario development tools to assist decision-makers and stakeholders in a shared dialogue $[18,60]$. This work complements those efforts by providing a stakeholder-based, adaptive approach that learns from 
others' experiences. While the specifics of each step will be different in other basins, the approach can be a valuable tool to adapt in other locales.

The first steps to implementing the identified four opportunities in the Potomac basin are establishing relationships with key land use decision-makers and, in conjunction with those partners, developing a mechanism for timely information dissemination. Through ongoing stakeholder discussions, the approach and objectives for human land use management in the basin will be modified in a fully adaptable fashion. The approach and outcomes will be reviewed and revised as part of the basin-wide comprehensive plan update.

\subsection{Partners}

In order to achieve the comprehensive plan's goal of sustainable water resource management, ICPRB aims to work with those making land use decisions at every level. Partnerships are essential to this goal, as there are so many agencies, organizations, and individuals making land use decisions every day. It may be impossible for ICPRB to effectively reach all of them directly. Therefore, ICPRB endeavors to identify those who have established connections with land use decision makers who could facilitate the sharing of information on land use practices for sustainable water resource management. A variety of organizations have these relationships and may be willing to participate (Figure 4). A complete list of agencies, representatives, and contact information has been compiled as an initial step in developing these relationships.

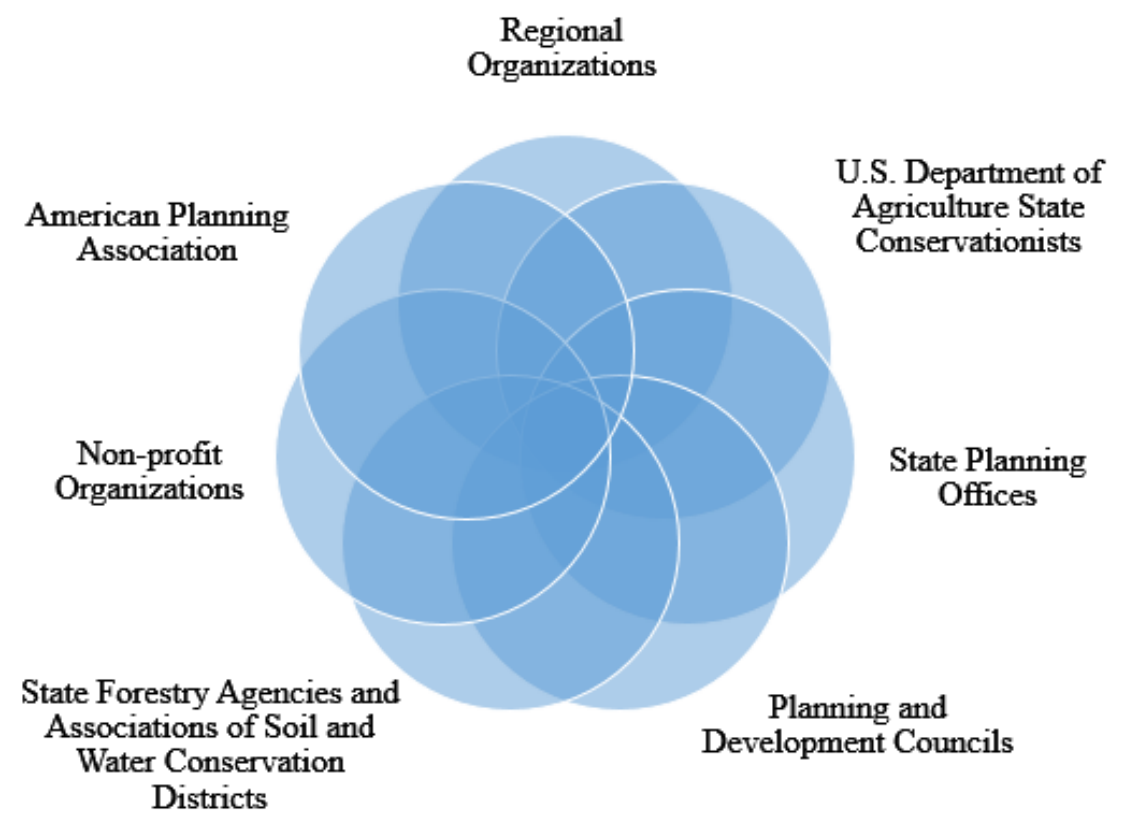

Figure 4. Organization types within the Potomac basin that have existing relationships with land use decision-makers.

\subsection{Method for Information Dissemination}

Land use management has far-reaching social, economic, environmental, and health effects. Within the Potomac basin, government agencies, institutions, advocacy groups, media organizations, researchers, and other interested stakeholders carry out communication activities using various techniques. However, despite their best attempts to protect the basin's natural resources, there is often a disconnect between the different entities. For example, the Potomac basin is made up of 49 counties, across four states and the District of Columbia, each with a different approach to land use and development. A collective approach to information dissemination between the localities could help to reduce the level of uncertainty associated with each program and improve the overall efficiency. 
As part of the implementation of the comprehensive plan, ICPRB is holding a workshop in the spring of 2020 on managing land use for sustainability. The workshop will target local land use decision-makers and will be an opportunity to further identify roles, responsibilities, areas of authority, and gaps in current activities. Discussions at that initial workshop will inform the design and implementation of future workshops and webinars for timely information sharing.

Using a webinar and workshop series, ICPRB is proposing to serve as a hub that connects the different local leaders and stakeholders and encourages them to engage each other and share strategies and approaches for land use management, such as innovations in water and land management, promoting incentives, and enhancing program integration, among others. Pending discussions with local decision-makers at the initial meeting, ICPRB plans to invite experts in different fields to address local leaders during the subsequent webinars and workshops. Webinars, in particular, are an effective method for information dissemination, because they break down participation barriers by eliminating the travel time for participants and presenters.

\section{Conclusions}

Deteriorating water quality, the lack of water availability at the time and place needed, and land degradation are global problems of utmost importance. As decisions made to manage land resources directly affect the quality and quantity of available water resources, it is imperative to jointly manage these resources for long-term sustainability. A basin-wide approach to integrating land and water management in the Potomac basin was shared in this paper.

The shared vision for the basin, developed by the plan's advisory committee, paints a future in which "... the Potomac River basin will serve as a national model for water resources management that fulfills human and ecological needs for current and future generations. The plan will focus on sustainable water resources management that provides the water quantity and quality needed for the protection and enhancement of public health, the environment, all sectors of the economy, and quality of life in the basin..." Achieving the long-term vision set forth in the basin's comprehensive plan will require collaborative, interdisciplinary action. ICPRB can serve as a catalyst for achieving the goals, but cannot be the sole actor. Basin stakeholders must act.

The component of achieving this vision discussed in this paper-sustainable decision-making for land and water resources-is a complex objective, especially in a multi-jurisdictional basin. A primary challenge is getting the right information to the right people at the right time in order to identify and implement good management decisions. This involves having partnerships with pertinent organizations and individuals, staying abreast of timely relevant information, and developing an efficient technical mechanism for distributing timely information. Funding is also a challenge. A plan for achieving each of these tasks was laid out in this paper. Specifically, efforts should include (1) improving access to information, (2) promoting incentives to achieve desired outcomes, (3) developing a framework that encourages innovation, and (4) integrating programs to achieve multiple objectives.

Integrating the approaches described in this paper into the existing regulatory, programmatic, and financial frameworks of the basin will require ongoing stakeholder commitment. Adapting human land use activities in the basin is a long-term process. Success will require outreach, open dialogue, and flexibility to evolve over time.

Author Contributions: Conceptualization, H.L.N.M. and K.B.; methodology, C.W.W. and E.S.; data curation, C.W.W. and E.S.; writing-original draft preparation and review, H.L.N.M., C.W.W., E.S. and K.B.; supervision, H.L.N.M.; All authors have read and agreed to the published version of the manuscript.

Funding: This project was supported by the Interstate Commission on the Potomac River Basin (ICPRB) and by the United States Environmental Protection Agency through CWA§106 grant 98339413.

Conflicts of Interest: The authors declare no conflict of interest. 


\section{References}

1. Abbott, B.W.; Bishop, K.; Zarnetske, J.P.; Minuado, C.; Chapin, F.S.; Krause, S.; Hannah, D.M.; Conner, L.; Ellison, D.; Godsey, S.E.; et al. Human Domination of the Global Water Cycle Absent from Depictions and Perceptions. Nat. Geosci. 2019, 12, 533-540. [CrossRef]

2. Giri, S.; Qiu, Z. Understanding the Relationship of Land Uses and Water Quality in the Twenty First Century: A Review. J. Environ. Manage. 2016, 173, 41-48. [CrossRef] [PubMed]

3. Chawla, I.; Mujumdar, P.P. Isolating the Impacts of Land Use and Climate Change on Streamflow. Hydrol. Earth Syst. Sci. 2015, 19, 3633-3651. [CrossRef]

4. USACE (United States Army Corps of Engineers); TNC (The Nature Conservancy); ICPRB. Middle Potomac River Watershed Assessment: Potomac River Sustainable Flow and Water Resources Analysis; Final Report; ICPRB: Rockville, MD, USA, 2014; p. 140.

5. Wang, X. Integrating Water-Quality Management and Land-Use Planning in a Watershed Context. J. Environ. Manag. 2001, 61, 25-36. [CrossRef] [PubMed]

6. Lacher, I.L.; Ahmadisharaf, E.; Fergus, C.; Akre, T.; Mcshea, W.J.; Benham, B.L.; Kline, K.S. Scale-dependent Impacts of Urban and Agricultural Land Use on Nutrients, Sediment, and Runoff. Sci. Total Environ. 2019, 652, 611-622. [CrossRef]

7. Shi, P.; Zhang, Y.; Li, Z.; Li, P.; Xu, G. Influence of Land use and Land Cover Patterns on Seasonal Water Quality at Multi-Spatial Scales. CATENA 2017, 151, 182-190. [CrossRef]

8. Mao, Y.; Liu, Y.; Li, H.; He, Q.; Ai, H.; Gu, W.; Yang, G. Distinct Responses of Planktonic and Sedimentary Bacterial Communities to Anthropogenic Activities: Case Study of a Tributary of the Three Gorges Reservoir, China. Sci. Total Environ. 2019, 682, 324-332. [CrossRef]

9. Moltz, H.L.N.; Palmer, J.B.; Smith, Z.M. Streamflow Alteration from Impervious Cover: Are All Watersheds Created Equal? J. Am. Water. Resour. Assoc. 2018, 54, 1222-1238. [CrossRef]

10. Jimenez-Madrid, A.; Carrasco, F.; Martinez, C. Activities Permitted Cartography: The Integration of Groundwater Protection into Land-Use Planning. Environ. Earth Sci. 2016, 75, 1372. [CrossRef]

11. Liu, Y.; Long, H.; Li, T.; Tu, S. Land Use Transitions and Their Effects on Water Environment in Huang-Huai-Hai Plain, China. Land Use Policy 2015, 47, 293-301. [CrossRef]

12. Gyawali, S.; Techato, K.; Monprapussorn, S.; Yuangyai, C. Integrating Land use and Water Quality for Environmental based Land Use Planning for U-tapao River Basin, Thailand. Procedia Soc. Behav. Sci. 2013, 91, 556-563. [CrossRef]

13. Carey, R.; Migliaccio, K.W.; Li, Y.; Schaffer, B.; Kiker, G.A.; Brown, M.T. Land Use Disturbance Indicators and Water Quality Variability in the Biscayne Bay Watershed, Florida. Ecol. Indic. 2011, 11, 1093-1104. [CrossRef]

14. Bodin, M. The Interdependence of Land and Water Protection. Available online: www.landtrustalliance.org/ news/interdependence-land-and-water-protection (accessed on 4 December 2019).

15. Duda, A.M.D. Co-Managing Land and Water for Sustainable Development. Available online: https: //knowledge.unccd.int/sites/default/files/2018-06/1.\%20Land-Water\%2BNexus_A_M_Duda.pdf (accessed on 18 July 2019).

16. Bolger, R.; Monsma, R.; Nelson, R. Sustainable Water Systems: Step One-Redefining the Nation's Infrastructure Challenge. Aspen Institute: Washington, DC, USA, 2009.

17. Phung, Q.A.; Thompson, A.L.; Baffaut, C.; Costello, C.; Sadler, E.J.; Svoma, B.M.; Lupo, A.; Gautam, S. Climate and Land Use Effects on Hydrologic Processes in a Primarily Rain-Fed Agricultural Watershed. J. Am. Water Resour. Assoc. 2019, 55, 1196-1215. [CrossRef]

18. Kraucunas, I.; Clarke, L.; Dirks, J.; Hathaway, J.; Hejazi, M.; Hibbard, K.; Huang, M.; Jin, C.; Kintner-Meyer, M.; van Dam, K.K.; et al. Investigating the Nexus of Climate, Energy, Water, and Land at Decision-Relevant Scales: The Platform for Regional Integrated Modeling and Analysis (PRIMA). Clim. Chang. 2015, 129, 573-588. [CrossRef]

19. Kim, J.; Ryu, J.H. Modeling Hydrological and Environmental Consequences of Climate Change and Urbanization in the Boise River Watershed, Idaho. J. Am. Water Resour. Assoc. 2018, 55, 133-153. [CrossRef]

20. NLCD (National Land Cover Database). NLCD 2011 Land Cover (2011 Edition, Amended 2014)—National Geospatial Data Asset (NGDA) Land Use Land Cover; 2011. Available online: https://www.mrlc.gov (accessed on 30 September 2019). 
21. Kenel, P.; Witherspoon, J.T. Practices to Promote Sustainable Water Sources. WEFTEC 2005. Available online: https://acwi.gov/swrr/Rpt_Pubs/wef_session68/068_0230.pdf (accessed on 3 October 2019).

22. WV DEP (West Virginia Department of Environmental Protection). West Virginia Water Resources Management Plan. 2013. Available online: www.dep.wv.gov/WWE/wateruse/WVWaterPlan/Pages/default. aspx (accessed on 2 August 2019).

23. ICPRB. Potomac River Basin Comprehensive Water Resources Plan. 2018, p. 112. Available online: www. potomacriver.org/wp-content/uploads/2018/06/Potomac_Comprehensive_Plan.pdf (accessed on 16 July 2019).

24. Sharifi, E. A Review of Local Planning Documents to Understand Practices Promoted through Land Use Planning across the Potomac River Basin. 2019. Available online: www.potomacriver.org/publications (accessed on 3 October 2019).

25. Ezezika, O.C.; Adetona, O. Resolving the gully erosion problem in Southeastern Nigeria: Innovation through public awareness and community-based approaches. J. Soil Sci. Environ. Manag. 2011, 2, $286-291$.

26. Marsalek, J.; Schreier, H. Innovation in Stormwater Management in Canada: The Way Forward. Water Qual. Res. J. Can. 2009, 44. [CrossRef]

27. EPA (Environmental Protection Agency). Federal Water Pollution Control Act. 2002; p. 234. Available online: www.epa.gov/sites/production/files/2017-08/documents/federal-water-pollution-control-act-508full. pdf (accessed on 24 September 2019).

28. EPA (Environmental Protection Agency). 2011 Maryland Standards and Specifications for Soil Erosion and Sediment Control. 2020. Available online: https://mde.maryland.gov/programs/Water/ StormwaterManagementProgram/Documents/2011\%20MD\%20Standard\%20and\%20Specifications\% 20for\%20Soil\%20Erosion\%20and\%20Sediment\%20Control.pdf (accessed on 9 June 2020).

29. Loudoun County. Revised 1993 Zoning Ordinance. 2019. Available online: www.loudoun.gov/ DocumentCenter/View/99645/Revised-1993-Zoning-Ordinance?bidId (accessed on 24 September 2019).

30. MDE (Maryland Department of the Environment). 2015 Maryland Soil Erosion and Sediment Control Standards and Specifications for Forest Harvest Operations. 2015. Available online: https:/mde.maryland.gov/programs/Water/ StormwaterManagementProgram/Documents/FHO\%20MANUAL\%20Dec\%207\%202015\%20Complete.pdf (accessed on 24 July 2019).

31. MDNR (Maryland Department of Natural Resources). Chesapeake Bay Implementation Grant. 2019. Available online: https://nnr.maryland.gov/ccs/Pages/funding/cbig.aspx (accessed on 24 July 2019).

32. Chesapeake Bay Program. Federal Leadership in Chesapeake Bay Protection and Restoration. 2009. Available online: https://federalleadership.chesapeakebay.net/page/About-the-Executive-Order.aspx (accessed on 23 June 2020).

33. MDE (Maryland Department of the Environment). Land Regulations. 2019. Available online: https: //mde.maryland.gov/programs/regulations/land/Pages/index.aspx (accessed on 23 June 2020).

34. Everything-PR. Chesapeake Bay Foundation Issues Maryland Lobbying Agency. 2019. Available online: https://everything-pr.com/chesapeake-bay-foundation-issues-maryland-lobbying-agency/ (accessed on 23 June 2020).

35. Chesapeake Bay Foundation. Maryland Office, Maryland. 2020. Available online: https://www.cbf.org/ about-cbf/locations/maryland/offices/annapolis/ (accessed on 23 June 2020).

36. Chesapeake Legal Alliance. Land Use and Habitat Protection. 2020. Available online: https://www. chesapeakelegal.org/bay-issues/land-use-and-habitat/ (accessed on 23 June 2020).

37. Chesapeake Bay. Protected Lands Outcome Management Strategy. 2019. Available online: https://www. chesapeakebay.net/documents/22065/2018-2019_protected_lands_management_strategy.pdf (accessed on 23 June 2020).

38. Chesapeake Bay Program. Local Leadership Outcome Management Strategy. 2019. Available online: https://www.chesapeakebay.net/documents/22051/2019-2020_local_leadership_workgroup_managment_ strategy_(updated_04.23.19).pdf (accessed on 23 June 2020).

39. Wetlands Watch. Implementing Resilience: The Barriers and Opportunities in Innovating Natural Resiliency Project Proposals. 2019. Available online: https:/static1.squarespace.com/static/56af7134be7b96f50a2c83e4/t/ 5d715eba77a52f0001781832/1567710915543/Final_CZM_Database_Report_webupload.pdf (accessed on 5 November 2019).

40. University of Maryland. Stormwater Management and Restoration Tracker. 2019. Available online: https://extension.umd.edu/watershed/smart-tool (accessed on 24 July 2019). 
41. Chesapeake Bay Trust. Green Streets, Green Jobs, Green Towns (G3). 2019. Available online: https: //cbtrust.org/wp-content/uploads/Green-Streets-RFP-2019-FINALv2.pdf (accessed on 24 July 2019).

42. DCR (Virginia Department of Conservation and Recreation). Virginia Soil and Water conservation board Guidance Document on the Tax Credit for Precision Agriculture Equipment. 2018. Available online: www.dcr.virginia.gov/soil-and-water/document/dcr-vswcb-044.pdf (accessed on 24 July 2019).

43. EPA (Environmental Protection Agency). Grant and Cooperative Agreement Guidance. 2018. Available online: https://www.epa.gov/sites/production/files/2016-01/documents/2016cbpograntguidance. pdf (accessed on 24 September 2019).

44. Chesapeake Bay Program. Residential Stewardship Practices. 2015. Available online: https://www.chesapeakebay. net/documents/U3._Residential_Stewardship_Practices_Fact_Sheet_in_Chesapeake_Bay_Watershed.pdf (accessed on 23 June 2020).

45. Forest for the Bay. Ecosystem Services Markets for VA Forestland. 2020. Available online: https: //www.forestsforthebay.org/ecosystem_services_markets.cfm?sid=VA (accessed on 23 June 2020).

46. PA DEP (Pennsylvania Department of Environmental Protection). Nutrient Trading. 2020. Available online: https://www.dep.pa.gov/Business/Water/CleanWater/NutrientTrading/Pages/default.aspx (accessed on 23 June 2020).

47. MDE (Maryland Department of the Environment). Accounting for Stormwater Waste load Allocations and Impervious Acres Treated. 2014. Available online: https://mde.state.md.us/programs/Water/ StormwaterManagementProgram/Documents/NPDES\%20MS4\%20Guidance\%20August\%2018\%202014. pdf (accessed on 23 June 2020).

48. Chesapeake Bay Foundation. Water Quality Trading. 2020. Available online: https://www.cbf.org/issues/ water-quality-trading/ (accessed on 23 June 2020).

49. Colosimo, M.F.; Kim, H. Incorporating Innovative Water Management Science and Technology into Water Management Policy. Energy Ecol. Environ. 2016, 1, 45-53. [CrossRef]

50. United States. The Endangered Species Act as Amended by Public Law; U.S. G.P.O.: Washington, DC, USA, 1983; pp. 97-304.

51. NRCS (Natural Resources Conservation Service). NRCS Funding Opportunities. 2019. Available online: https://www.nrcs.usda.gov/wps/portal/nrcs/detail/national/programs/?\&cid=stelprdb1048817 (accessed on 5 November 2019).

52. Fairfax County. Conservation Assistance Program for Civic/Homeowners Associations and Places of Worship. 2019. Available online: www.fairfaxcounty.gov/soil-water-conservation/cap-community (accessed on 24 July 2019).

53. Chesapeake Bay Program. Grants \& RFPs. 2019. Available online: https://www.chesapeakebay.net/what/ grants (accessed on 5 November 2019).

54. EPA (Environmental Protection Agency). Funding Opportunities in the Chesapeake Bay Watershed. 2019. Available online: https://www.epa.gov/chesapeake-bay-tmdl/funding-opportunities-chesapeake-baywatershed (accessed on 5 November 2019).

55. EPA (Environmental Protection Agency). EPA and American Rivers Award $\$ 1.37$ Million in Grants to Restore Potomac Highlands Rivers, Clean Water. 2012. Available online: https://archive.epa.gov/epapages/ newsroom_archive/newsreleases/c00051390ddf0af4852579de005287a7.html (accessed on 5 November 2019).

56. Chesapeake Bay Program. Land Use Program. 2020. Available online: https://www.chesapeakebay.net/who/ group/land_use_workgroup (accessed on 23 June 2020).

57. California Council on Science and Technology. Achieving a Sustainable California Water Future through Innovations in Science and Technology. 2014. Available online: www.calstate.edu/water/documents/ Achieving-Sustainable.pdf (accessed on 3 October 2019).

58. Winterbottom, R.; Reij, C.; Garrity, D.; Glover, J.; Hellums, D.; McGahuey, M.; Scherr, S. Improving Land and Water Management: Creating a Sustainable Food Future, Installment Four; World Resources Institute: Washington DC, USA, 2013; p. 44. Available online: https://wriorg.s3.amazonaws.com/s3fs-public/improving_land_and_ water_management_0.pdf (accessed on 3 October 2019).

59. National Academy of Science. What Approaches are Most Likely to Encourage the Adoption of Best Management Practices? In National Summit on Strategies to Manage Herbicide-Resistant Weeds. National Research Council; The National Academies Press: Washington, DC, USA, 2012; Available online: https: //www.nap.edu/read/13518/chapter/1 (accessed on 3 October 2019). 
60. Lechner, A.M.; McIntyre, N.; Bulovic, N.; Kujala, H.; Whitehead, A.; Webster, A.; Wintle, B.; Rifkin, W.; Scott, M. A GIS tool for land and water use planning in mining regions. In Proceedings of the 21st International Congress on Modelling and Simulation, Gold Coast, Australia, 29 November-4 December 2015.

61. Hoekstra, A.Y.; Mekonnen, M.M. The water footprint of humanity. Proc. Natl. Acad. Sci. USA 2012, 109, 3232-3237. [CrossRef]

62. Steele, D.D.; Stegman, E.C.; Knighton, R.E. Irrigation management for corn in the northern Great Plains, USA. Irrig. Sci. 2000, 19, 107-114. [CrossRef]

63. Knight, R.L. Conservation for a New Generation: Redefining Natural Resources Management; Island Press: Washington, DC, USA, 2008; ISBN 978-1-59726-921-6.

64. Dill, J.; Howe, D.A. Land Use Innovation: Experiences in the Adoption of Land Use Policies to Promote Active Living. In Proceedings of the Active Living Research Annual Conference, San Diego, CA, USA, 9-11 February 2010; Volume 16.

65. USDA (United States Department of Agriculture). National Farmers Market Manager Survey Summary: A Snapshot of the 2013 Farmers Market Season. In Agricultural Marketing Service; USDA: Washington, DC, USA, 2014; p. 2.

66. Esri ArcGIS Online. 2020. Available online: https://www.esri.com/en-us/arcgis/products/arcgis-online/ overview (accessed on 31 May 2020).

67. GeoCommunity. Here Comes ArcView 8.1. 2008. Available online: https://web.archive.org/web/ 20080210033440/http://spatialnews.geocomm.com/features/arcview81/ (accessed on 31 May 2020).

68. Direct Market Farmers. American Farmland Trust and Farmers Market Coalition, National Survey. Unpublished Raw Data. 2015. Available online: https:/farmersmarketcoalition.org/wp-content/uploads/2016/ 07/FMC_TalkingPoints_2016.pdf (accessed on 24 October 2019).

69. Weber, C.L.; Matthews, H.S. Food-Miles and the Relative Climate Impacts of Food Choices in the United States. Environ. Sci. Technol. 2008, 42, 3508-3513. [CrossRef] [PubMed]

70. Samuels \& Associates. Increasing Access to Healthy Food in the Central Valley through Farmers Markets and Produce Stands. 2010. Available online: www.cultivalasalud.org/wp-content/uploads/2015/06/B_CCROPP_ FM.pdf (accessed on 17 October 2019).

71. Alkon, A. Paradise or pavement: The social constructions of the environment in two urban farmers' markets and their implications for environmental justice and sustainability. Local Environ. 2008, 13, 271-289. [CrossRef]

72. Young, C.; Karpyn, A.; Uy, N.; Wich, K.; Glyn, J. Farmers' markets in low income communities: Impact of community environment, food programs and public policy. Community Dev. 2011, 42, 208-220. [CrossRef]

73. Trobe, H.L. Farmers' markets: Consuming local rural produce. Int. J. Consum. Stud. 2001, 25, 181-192. [CrossRef]

74. EPA (Environmental Protection Agency). Economic Incentives. 2019. Available online: www.epa.gov/ environmental-economics/economic-incentives (accessed on 3 October 2019).

75. Alliance for the Chesapeake Bay. Incentive Programs. 2019. Available online: www.stormwater. allianceforthebay.org/riverwise-communities-manual/incentive-programs (accessed on 3 October 2019).

76. Commonwealth of Virginia. Strategies for Financing Chesapeake Bay Restoration in Virginia. 2017. Available online: www.chesapeakebay.net/documents/Strategies_for_Financing_Ches_Bay_Restoration_in_ VA_FINAL_9.26.17.pdf (accessed on 7 October 2019).

77. Environmental Finance Center at the University of Maryland. Financial Incentives for Water Quality Protection and Restoration on Agricultural Lands in Pennsylvania. 2016. Available online: www.chesapeakebay.net/channel_ files/23872/financial_incentives_for_conservation_on_ag_lands_9-28-16.pdf (accessed on 7 October 2019).

78. WERF (Water Environment Research Foundation). Using Incentive Programs to Promote Stormwater BMPs. 2019. Available online: www.werf.org/liveablecommunities/toolbox/incentives.htm (accessed on 3 October 2019).

79. EPA (Environmental Protection Agency). Managing Wet Weather with Green Infrastructure Municipal Handbook, Incentive Mechanisms; EPA-833-F-09-001; 2009. Available online: www.epa.gov/sites/production/ files/2015-10/documents/gi_munichandbook_incentives.pdf (accessed on 3 October 2019).

80. HarvestH20. Rainwater and Water Conservation Incentives. 2019. Available online: www.harvesth2o.com/ incentives (accessed on 17 October 2019). 
81. Nattress, T. Five Communication Tips for Stormwater Incentive Programs. 2017. Available online: http: //efc.web.unc.edu/2017/11/22/five-communication-tips-for-stormwater-incentive-programs (accessed on 3 October 2019).

82. Heimlich, R.E.; Anderson, W.D. Development at the Urban Fringe and Beyond: Impacts on Agriculture and Rural Land; Agricultural Economic Report No. 803; U.S. Department of Agriculture: Washington, DC, USA, 2001.

83. Goonetilleke, A.; Vithanage, M. Water Resources Management: Innovation and Challenges in a Changing World. Water 2017, 9, 281. [CrossRef]

84. Cosgrove, W.J.; Loucks, D.P. Water Management: Current and Future Challenges and Research Directions. Water Resour. Res. 2015, 51, 4823-4839. [CrossRef]

85. Manso, G. Creating Incentives for Innovation. Calif. Manag. Rev. 2017, 60, 18-32. [CrossRef]

86. Rockefeller Foundation. Incentive-Based Instruments for Water Management, Synthesis Review; New York NY, USA, 2015. Available online: https://pacinst.org/wp-content/uploads/2016/02/issuelab_23697.pdf (accessed on 7 October 2019).

87. Amabile, T.; Khaire, M. Creativity and the Role of the Leader. Harvard Business Review 2008, 86, 100-109.

88. Berry, D. Encouraging Local Environmental Innovation. 2008. Available online: https://www. thesolutionsjournal.com/article/encouraging-local-environmental-innovation/ (accessed on 10 August 2020).

89. Anadon, L.D.; Chan, G.; Harley, A.G.; Matus, K.; Moon, S.; Murthy, S.L.; Clark, W.C. Making Technical Innovation Work for Sustainable Development. Proc. Natl. Acad. Sci. USA 2016, 113, 9682-9690. [CrossRef]

90. Ajami, N.K.; Thompson, B.H.; Victor, D.G. The Path to Water Innovation; Stanford Woods Institute for the Environment: Stanford, CA, USA, 2014; p. 40.

91. Value of Water Coalition. The New Wave of Water Innovation. 2015. Available online: http://uswateralliance.org/sites/uswateralliance.org/files/publications/New\%20Wave\%20of\%20Water\% 20Innovation_Value\%20of\%20Water\%20Coalition_May\%202015.pdf (accessed on 17 October 2019).

92. EPA (Environmental Protection Agency). Examples of Innovation in the Water Sector. 2019. Available online: www.epa.gov/water-innovation-tech/examples-innovation-water-sector (accessed on 17 October 2019).

93. DC Water. Long Term Control Plan Modification for Green Infrastructure. 2015. Available online: https: //www.dcwater.com/sites/default/files/green-infrastructure-ltcp-modificaitons.pdf (accessed on 3 December 2019).

94. Christian-Smith, J.; Gleick, P.H.; Cooley, H.U.S. Water Policy Reform. In The World's Water; Gleick, P.H., Ed.; Island Press/Center for Resource Economics: Washington, DC, USA, 2012; pp. 143-155, ISBN 978-1-61091-048-4.

95. Loucks, D.P.; van Beek, E. Water Resources Planning and Management: An Overview. In Water Resource Systems Planning and Management: An Introduction to Methods, Models, and Applications; Loucks, D.P., van Beek, E., Eds.; Springer International Publishing: Cham, Switzerland, 2017; pp. 1-49, ISBN 978-3-319-44234-1.

96. Utah State University. Integrating Water Resources and Land Use Planning. 1979. Available online: https: //digitalcommons.usu.edu/cgi/viewcontent.cgi?article=1190\&context=water_rep (accessed on 31 May 2020).

97. USACE (United States Army Corps of Engineers). Chesapeake Bay: Final Comprehensive Water Resources and Restoration Plan. 2019. Available online: www.nab.usace.army.mil/Missions/Civil-Works/ChesapeakeBay-Comprehensive-Plan (accessed on 7 October 2019).

98. Angelo, M.J. Integrating Water Management and Land Use Planning: Uncovering the Missing Link in the Protection of Florida's Water Resources. Univ. Fla. J. Law Public Policy 2000, 12, 223.

99. Croke, J.; Hairsine, P.; Fogarty, P. Soil Recovery from Track Construction and Harvesting Changes in Surface Infiltration, Erosion and Delivery Rates with Time. Forest. Ecol. Manag. 2001, 143, 3-12. [CrossRef]

100. Tague, C.; Band, L. Simulating the Impact of Road Construction and Forest Harvesting on Hydrologic Response. Earth Surf. Processes Land. 2001, 26, 135-151. [CrossRef]

101. Wolman, M.G.; Schick, A.P. Effects of Construction on Fluvial Sediment, Urban and Suburban Areas of Maryland. Water Resour. Res. 1967, 3, 451-464. [CrossRef]

102. Sun, G.; Caldwell, P. Impacts of Urbanization on Stream Water Quantity and Quality in the United States. Water Resour. Impact 2015, 17, 4.

103. Hughes, R.M.; Dunham, S.; Maas-Hebner, K.G.; Yeakley, J.A.; Schreck, C.; Harte, M.; Molina, N.; Shock, C.; Kaczynski, V.; Schaeffer, J. A Review of Urban Water Body Challenges and Approaches: (1) Rehabilitation and Remediation. Fisheries 2014, 39, 18-29. [CrossRef] 
104. Srinivasan, V.; Seto, K.C.; Emerson, R.; Gorelick, S.M. The Impact of Urbanization on Water Vulnerability: A Coupled Human-Environment System Approach for Chennai, India. Glob. Environ. Chang. 2013, 23, 229-239. [CrossRef]

105. Moltz, H.L.N.; Mandel, R.; Bencala, K.R.; Palmer, J.B.; Nagel, A.; Kaiser, S.; Gorzalski, A. Forest Cover Impacts on Drinking Water Utility Treatment Costs in a Large Watershed; The Water Research Foundation: Alexandria, VA, USA, 2018.

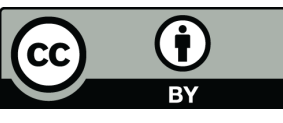

(C) 2020 by the authors. Licensee MDPI, Basel, Switzerland. This article is an open access article distributed under the terms and conditions of the Creative Commons Attribution (CC BY) license (http://creativecommons.org/licenses/by/4.0/). 